\title{
Welder identity, weld date, and the risk of outlet strut fracture in Björk-Shiley convexo-concave valves: the Dutch cohort study
}

\author{
Marjon Kallewaard, Ale Algra, Yolanda van der Graaf
}

\begin{abstract}
Objective-To establish whether there is an association between subsequent fracture of the outlet strut and welder identity and the weld date of Björk-Shiley convexo-concave (BScc) valves.

Design-Cohort study.

Patients-All Dutch BScc valve recipients $(\mathrm{n}=2266)$.

Mean outcome measures-Documented outlet strut fracture during follow up.

Results-Weld dates were known for $97 \cdot 0 \%$ of all BScc valves $(n=2534)$ implanted in Dutch patients $(n=2266)$ and welder identity was known for $52 \cdot 2 \%$. During a mean follow up of 9.4 years, 46 fractures were documented. For $60^{\circ}$ valves welded from 1981 to 1984 the fracture rate $(0.22$ per 100 person-years $(95 \%$ CI 0.13 to 0.34$)$ ) was higher than that for valves welded before $1981(0.04$ (95\% CI $0 \cdot 01-0 \cdot 10)$ ). When all fracture related risk factors were taken into account, fracture rates per welder did not show any statistically significant differences.

Conclusions-Welder identity does not contribute to the risk of strut fracture. Other factors in the production of BScc valves may explain the increased risk for valves welded from 1981 to 1984.
\end{abstract}

(Heart 1996;76:510-512)

Keywords: heart valve prosthesis; welder identity; strut fracture; Björk-Shiley CC valve

Björk-Shiley convexo-concave (BScc) valves are apt to fracture at the outlet strut. ${ }^{1-3}$ A population based follow up study conducted in the Netherlands indicated that valve opening angle $\left(70^{\circ}\right)$, valve diameter $(\geqslant 29 \mathrm{~mm})$, valve

Department of Clinical Epidemiology, School of Medicine, Utrecht University, The Netherlands M Kallewaard A Algra

Y van der Graaf

Correspondence to: $M$ Kallewaard, Clinical Epidemiology Unit, School of Medicine, Utrecht University, PO Box 80035, 3508 TA Utrecht, The Netherlands.

Accepted for publication 21 June 1996 by use of additional data on welding obtained from Shiley.

\section{Patients and methods}

PATIENTS

The study-cohort consisted of all Dutch BScc valve recipients $(n=2266)$, identified during the first BScc follow up study'; faults in the data were corrected and the cohort was updated. The follow up was extended until 1 September 1995. Mean duration of follow up was $9 \cdot 4$ years. Forty eight patients $(2 \cdot 1 \%)$ had incomplete follow up. Forty six fractures were documented. Three fractures were reported after the closing date of the study.

\section{WELDING INFORMATION}

Welding information was obtained from weld charts, which are strip charts on which the current used during welding of BScc valves was recorded. These charts also recorded the identification number, employee number(s) of the welder(s), and weld date of the batch of valves being welded. Sometimes more than one welder worked on a batch of valves, making it impossible to determine which welder worked on which valve from that particular batch. Weld charts were first used in June 1980; their use stopped in June 1983 after the charts were found not to be useful.

For valves for which no weld charts were available, the welder identity could not be established. Weld dates for these valves were obtained from the fabrication orders.

\section{STATISTICAL ANALYSIS}

We studied the relation of welder identity and weld date to the occurrence of strut fracture. We stratified for opening angle and valve size, which are both risk factors for strut fracture. ${ }^{1-3}$ Two different analytical approaches were used. Firstly, fracture rates were computed per single welder or combination of welders listed on the weld charts. Secondly, rates were calculated if a given welder worked solely or in collaboration with other welders on the production of a batch. $60^{\circ} \mathrm{BScc}$ valves welded from January 1981 through June 1982 have been reported to be at higher risk of fracture. ${ }^{26}$ We therefore dichotomised weld date according to whether valves were welded before or after January 1981. Fracture rates were expressed as numbers of fractures per 100 person years of observation. Details are reported in the first report on the Dutch BScc follow up 
Table 1 Fracture rates (per 100 person-years) per welder or combination of welders, stratified for opening angle for valves from 1981-1984

\begin{tabular}{|c|c|c|c|c|c|c|c|c|c|c|}
\hline \multirow[b]{2}{*}{ Welder employee-number } & \multicolumn{5}{|l|}{$60^{\circ}$ Valves } & \multicolumn{5}{|c|}{$70^{\circ}$ Valves } \\
\hline & Fractures & Valves & $\begin{array}{l}\text { Person- } \\
\text { years }\end{array}$ & $\begin{array}{l}\text { Rate (per } 100 \\
\text { person-years) }\end{array}$ & $95 \% C I$ & Fractures & Valves & $\begin{array}{l}\text { Person- } \\
\text { years }\end{array}$ & $\begin{array}{l}\text { Rate (per } 100 \\
\text { person-years) }\end{array}$ & $95 \% C I$ \\
\hline No weld chart & 0 & 86 & 703 & 0 & $(0$ to 0.52$)$ & 0 & 0 & & & \\
\hline Welder I & 0 & 96 & 834 & 0 & (0 to 0.44$)$ & 0 & 0 & & & \\
\hline Welder II & 4 & 169 & 1625 & $0 \cdot 25$ & $(0.07$ to 0.63$)$ & 7 & 88 & 569 & $1 \cdot 23$ & $(0.49$ to 2.53$)$ \\
\hline Welder III & 3 & 133 & 1160 & $0 \cdot 26$ & $(0.05$ to 0.76$)$ & 5 & 51 & 432 & $1 \cdot 16$ & $(0 \cdot 38$ to $2 \cdot 70)$ \\
\hline Welder IV & 0 & 15 & 145 & 0 & (0 to 2.54 ) & 2 & 15 & 106 & 1.89 & $(0 \cdot 23$ to $6 \cdot 82)$ \\
\hline Welders II and III & 4 & 233 & 2035 & $0 \cdot 20$ & $(0.05$ to 0.50$)$ & 2 & 77 & 588 & 0.34 & $(0.04$ to 1.23$)$ \\
\hline Welders II and IV & 1 & 34 & 302 & $0 \cdot 33$ & $(0.01$ to 1.84$)$ & 3 & 17 & 145 & $2 \cdot 07$ & $(0.43$ to 6.05$)$ \\
\hline Welders III and IV & 4 & 74 & 673 & 0.59 & $(0.16$ to 1.52$)$ & 1 & 14 & 114 & $0 \cdot 88$ & $(0.02$ to 4.89$)$ \\
\hline Welders II and others & 0 & 3 & 22 & 0 & (0 to $16 \cdot 77)$ & 0 & 0 & & & \\
\hline Welders III and others & 2 & 51 & 486 & 0.41 & $(0.05$ to 1.49$)$ & 0 & 0 & & & \\
\hline Welders IV and others & 0 & 11 & 111 & 0 & (0 to 3.32$)$ & 0 & 3 & 19 & 0 & (0 to $19 \cdot 42)$ \\
\hline Other welders & 1 & 50 & 455 & $0 \cdot 22$ & $(0.01$ to 1.22$)$ & 1 & 4 & 41 & $2 \cdot 44$ & $(0.06$ to 13.59$)$ \\
\hline Three or more welders & 0 & 15 & 157 & 0 & (0 to $2 \cdot 35)$ & 1 & 3 & 18 & $5 \cdot 56$ & $(0.14$ to 30.95$)$ \\
\hline
\end{tabular}

study. ${ }^{1}$ 95\% Confidence intervals were based on the Poisson distribution.?

\section{Results}

Weld charts were available for $1052(46 \cdot 6 \%)$ $60^{\circ}$ valves $(\mathrm{n}=2257)$ and $272(98.2 \%) 70^{\circ}$ valves $(n=277)$. A single welder was involved in welding 723 valves $(54.6 \%)$, two welders in $582(44.0 \%)$, three welders in $13(1.0 \%)$, and four welders in six $(0.5 \%)$. Ten employee numbers were identified. Welders II and III were involved in welding 1117 valves $(84 \cdot 4 \%)$. Welder IV was listed on the weld charts of 197 valves $(14.9 \%)$, most of the time in combination with another employee. Welder I was the single welder of $9660^{\circ}$ valves.

Only five fractures were documented among $121660^{\circ}$ valves welded before 1981 , compared with 19 fractures among $97060^{\circ}$ valves welded from 1981 onwards (fracture rates $0.04(95 \%$ CI 0.01 to 0.10$)$ and 0.22 (95\% CI 0.13 to 0.34$)$ per 100 person years, respectively). One $70^{\circ}$ valve was welded before 1981. Twenty two fractures were reported among $27270^{\circ}$ valves welded from 1981 to 1984 (fracture rate $1.08(95 \%$ CI 0.68 to $1.64)$ per 100 person years). The weld date was unknown for 75 valves $(3.0 \%)$; no fractures were documented.

Further analyses were restricted to valves welded from 1981 to 1984 . Table 1 shows the fracture rates per single welder or combination of welders listed on the weld charts. Among the $60^{\circ}$ and $70^{\circ}$ valves no single welder or combination of welders can be identified at higher risk of fracture. Although fracture rates differ, $95 \%$ confidence intervals show considerable overlap.

Table 2 presents fracture rates per employee number listed, irrespective whether a single employee number or multiple employee numbers were listed on the weld chart. For both $60^{\circ}$ and $70^{\circ}$ valves, and for both small $(<29 \mathrm{~mm})$ and large $(\geqslant 29 \mathrm{~mm})$ valves, fracture rates were higher if welder IV was listed on the weld chart. Again the confidence intervals were wide and no statistical differences between the welders were observed.

\section{Discussion}

In this study, no welder could be identified as risk factor for strut fracture. Fracture rates for valves welded from 1981 to 1984 were considerably higher than for valves welded before 1981.

Several of our methods deserve comment. Firstly, we could not establish welder identity for $1210(47 \cdot 8 \%)$ valves. However, among these valves only five fractures occurred; most of these valves $(86 \cdot 7 \%)$ were welded before 1981. Secondly, most batches were welded by two or more welders. We used two different approaches to calculate the fracture rates per

Table 2 Fracture rates (per 100 person-years) by welder involved, stratified for opening angle and valve size for valves welded 1981-1984

\begin{tabular}{|c|c|c|c|c|c|c|c|c|c|c|}
\hline \multirow[b]{2}{*}{ Welder involvement } & \multicolumn{5}{|l|}{$60^{\circ}$ Valves } & \multicolumn{5}{|c|}{$70^{\circ}$ Valves } \\
\hline & Fractures & Valves & $\begin{array}{l}\text { Person- } \\
\text { years }\end{array}$ & $\begin{array}{l}\text { Rate (per } 100 \\
\text { person-years) }\end{array}$ & $95 \% C I$ & Fractures & Valves & $\begin{array}{l}\text { Person- } \\
\text { years }\end{array}$ & $\begin{array}{l}\text { Rate (per } 100 \\
\text { person-years) }\end{array}$ & $95 \% C I$ \\
\hline No weld chart & 0 & 86 & 703 & 0 & (0 to 0.52 ) & 0 & 0 & & & \\
\hline Welder I & 0 & 96 & 834 & 0 & ( 0 to 0.44 ) & 0 & 0 & & & \\
\hline Welder II & 9 & 454 & 4141 & $0 \cdot 22$ & $(0.10$ to 0.41$)$ & 13 & 185 & 1320 & 0.98 & $(0.52$ to 1.68$)$ \\
\hline Welder III & 13 & 500 & 4437 & $0 \cdot 29$ & $(0.16$ to 0.50$)$ & 9 & 145 & 1152 & $0 \cdot 78$ & $(0.36$ to 1.48$)$ \\
\hline Welder IV & 5 & 145 & 1344 & $0 \cdot 37$ & $(0.12$ to 0.87$)$ & 7 & 52 & 402 & 1.74 & $(0.70$ to 3.59$)$ \\
\hline Other welders & 3 & 125 & 1193 & $0 \cdot 25$ & $(0.05$ to 0.73$)$ & 1 & 7 & 60 & 1.67 & $(0.04$ to 9.29$)$ \\
\hline \multirow[t]{2}{*}{ All } & 19 & 970 & 8708 & $0 \cdot 22$ & $(0.13$ to 0.34$)$ & 22 & 272 & 2031 & 1.08 & $(0.68$ to 1.64$)$ \\
\hline & \multicolumn{5}{|c|}{ Size $<29 \mathrm{~mm}$} & \multicolumn{5}{|c|}{ Size $\geqslant 29 \mathrm{~mm}$} \\
\hline No weld chart & 0 & 38 & 305 & 0 & $(0$ to $1 \cdot 21)$ & 0 & 48 & 398 & 0 & $(0$ to $1 \cdot 21)$ \\
\hline Welder I & 0 & 66 & 569 & 0 & (0 to 0.65$)$ & 0 & 30 & 264 & 0 & (0 to 1.39$)$ \\
\hline Welder II & 4 & 403 & 3578 & $0 \cdot 11$ & $(0.03$ to 0.29$)$ & 18 & 236 & 1882 & $0 \cdot 96$ & $(0.57$ to 1.51$)$ \\
\hline Welder III & 4 & 416 & 3672 & $0 \cdot 11$ & $(0.03$ to 0.28$)$ & 18 & 229 & 1916 & 0.94 & $(0.56$ to 1.48$)$ \\
\hline Welder IV & 4 & 114 & 1093 & $0 \cdot 37$ & $(0.10$ to 0.94$)$ & 8 & 83 & 652 & $1 \cdot 23$ & ( 0.53 to 2.42$)$ \\
\hline Other welders & 1 & 111 & 1057 & 0.09 & $(<0.01$ to 0.53$)$ & 3 & 21 & 196 & 1.53 & $(0.32$ to 4.47$)$ \\
\hline All & 10 & 795 & 7060 & $0 \cdot 14$ & $(0.07$ to 0.26$)$ & 31 & 447 & 3679 & $0 \cdot 84$ & $(0.57$ to 1.20$)$ \\
\hline
\end{tabular}


welder. The fracture rates yielded by both approaches were consistent with each other. Thirdly, our conclusions are hampered by the limited number of fractures, especially after stratification for the most important fracture related risk factors-opening angle and valve size. Finally, we only studied the relation between welder identity and weld date and the risk of fracture. The structure of a weld, however, depends on the raw material being used and the conditions under which a welder operates. ${ }^{8}$ These and other factors in the welding process, which could not be identified by us, may contribute to the risk of fracture.

Shiley has suggested that the fracture problem is caused by over-rotation of the disc. ${ }^{29}$ To solve this problem the manufacturing process was changed in early April 1984. No fractures have been reported among the few valves processed after that date. Our finding of a higher fracture rate for valves welded from 1981 to 1984 suggests that other factors in the manufacturing process also contribute to the risk of fracture. Recently manufacturing data, other than the weld charts, were made available to us. These documents are now being abstracted. By studying the manufacturing process we hope to determine factors that explain the difference in risk between valves welded before and after 1981 .

1 van der Graaf $Y$, de Waard F, van Herwerden LA, Defauw J. Risk of strut fracture of Björk-Shiley valves. Lancet 1992;339:257-61.

2 Hiratzka LF, Kouchoukos NT, Grunkemeier GL, Miller DC, Scully HE, Wechsler AS. Outlet strut fracture of the Björk-Shiley 60 degrees Convexo-Concave valve: current Bjork-Shiley 60 degrees Convexo-Concave valve: current information and recommendati

3 Lindblom D, Rodriguez L, Björk VO. Mechanical failure of the Björk-Shiley valve. Updated follow-up and considerations on prophylactic rereplacement. $\mathcal{f}$ Thorac Cardiovasc Surg 1989;97:95-7.

4 Sacks SH, Harrison M, Bischler PJ, Martin JW, Watkins J, Gunning A. Metallurgical analysis of failed Björk-Shiley cardiac valve prostheses. Thorax 1986;41:142-7.

5 de Mol BA, Kallewaard M, McLellan RB, van-Herwerden LA, Defauw JI, van der Graaf Y. Single-leg strut fractures in explanted Björk-Shiley valves. Lancet 1994;343:9-12.

6 Hedger P. Important update information for physicians about patients with Biörk-Shiley convexo-concave 60 degree heart valves. Dear Doctor letters. Irvine, CA Shiley Inc, 1995.

7 Poisson-Verteilung. 95\%-Vertrauensgrenzen für $\lambda$. In Diem K, ed. Documenta Geigy Wissenschaftliche Tabellen. Basel: JR Geigy AG, Pharmazeutische Abteilung, Basel: JR

8 Röckelein G, Breme J, Emde J von der. Lethal blockage of a Björk-Shiley artificial heart valve caused by strut frac-
Buckele ture-the metallurgical aspect. Thorac Cardiovasc Surg 1989;37:47-51.

9 Ostermeyer J, Horstkotte D, Bennett J, Huysmans H, Lindblom D, Olin C, et al. The Björk-Shiley 70 degree convexo-concave prosthesis strut fracture problem (present state of information). Thorac Cardiovasc Surg 1987;35:71-7. 